\title{
Evolution of tropical termites in early Paleogene with description of a new species of Stylotermitidae (Isoptera) from Rovno amber (late Eocene of Ukraine)
}

\author{
E.E. Perkovsky ${ }^{1}$, D.V. Vasilenko ${ }^{2,3}$ \\ ${ }^{1}$ I.I. Schmalhausen Institute of Zoology, Bogdan Chmielnitski Str., 15, Kiev, 01601 Ukraine. \\ E-mail:perkovsk@gmail.com \\ ${ }^{2}$ A.A. Borissiak Paleontological Institute, Russian Academy of Sciences, Profsoyuznaya Str. 123, \\ Moscow, 117868 Russia. \\ ${ }^{3}$ Cherepovets State University, Lunacharsky prospect 5, Cherepovets, Vologda region, 162600 \\ Russia.E-mail:damageplant@mail.ru
}

ABSTRACT. The first Rovno amber stylotermitid Parastylotermes nathani Perkovsky sp.n. is described. It is the fourth amber stylotermitid and the second Priabonian one. Two non-Priabonian amber stylotermitids are known from the tropical Ypresian Cambay amber. In Cambay amber stylotermitids compose half of the species, and all termites with trimerous tarsi extraordinary $75 \%$ of Cambay termites. Another peculiarity of the Cambay amber isopteran community is the small body size: Cambay termites are 2.3-2.6 times smaller than Aptian Crato and Cenomanian Burmese termites and two times smaller than Ypresian Oise amber termites. The dominance of small termites with trimerous tarsi in Cambay amber is likely because of a change in the nature of predation pressure in the tropics during the earliest Cenozoic. The only known Cretaceous arboreal birds belonged to Enantiornithes (opposite birds). These opposite birds are known to have low cranial kinetism and thus would have difficulty catching small insects. At the K-Pg boundary, the extinction of Enantiornithes occurred. Concurrent with this event there was a rapid radiation of crown birds and their expansion in the low latitudes, increasing pressure from predation. The smallest $(2 \mathrm{~mm}$ ) isopteran, Nanotermes (earliest termitid), was found in Cambay amber. The strong miniaturization of the earliest termitids would be instrumental in the loss of obligate intestinal protozoa symbionts. These protists were too big become fully established in the narrow gut of small third instar of the earliest termitids. The loss of dependence on protists resulted in the loss of most larval instars in termitids and irreversible separation of neuter and sexual lines, paving the way to their ecological dominance in the tropics.

How to cite this paper: Perkovsky E.E., Vasilenko D.V.2020. Evolution of tropical termites in early Paleogene with description of a new species of Stylotermitidae (Isoptera) from Rovno amber (late Eocene of Ukraine) // Invert. Zool. Vol.17. No.3. P.231-246. doi: 10.15298/invertzool.17.3.03

KEY WORDS. Parastylotermes nathani sp.n., Nanotermes, Enantiornithes, miniaturization, Termitidae, loss of the obligate symbiosis with intestinal protozoa, ecological domination. 


\title{
Эволюция тропических термитов в раннем палеогене с описанием нового вида Stylotermitidae (Isoptera) из ровенского янтаря (поздний эоцен Украины)
}

\author{
Е.Э. Перковский' , Д.В. Василенко 2,3 \\ ${ }^{1}$ Институт зоологии им. И.И. Шмальгаузена НАН Украины, ул. Б. Хмельницкого, 15, Киев, \\ 01030, Украина. E-mail:perkovsk@gmail.com \\ ${ }^{2}$ Палеонтологический институт им. А.А. Борисяка РАН, Профсоюзная ул. 123, Москва \\ 117997, Россия. \\ ${ }^{3}$ Череповеикий государственный университет, пр. Луначарского 5, Череповеи, Вологодская \\ обл., 162600 Россия. E-mail:damageplant@mail.ru
}

РЕЗЮМЕ. Описан первый вид стилотермитид из ровенского янтаря, Parastylotermes nathani Perkovsky sp.n. Это четвёртый янтарный и второй приабонский вид стилотермитид; два других вида янтарных стилотермитид известны из тропического ипрского камбейского янтаря. В камбейском янтаре стилотермитиды составляют половину видов, а все термиты с трехчлениковыми лапками даже три четверти всех видов термитов. Другой особенностью камбейских термитов являются мелкие размеры: камбейские термиты в 2,3-2,5 раза мельче аптских термитов Сантаны и сеноманских термитов бирманского янтаря и в 2 раза мельче ипрских термитов из янтаря Уазы. Доминирование мелких термитов с трехчлениковыми лапками в камбейском янтаре может быть обусловлено изменением характера пресса хищников в тропиках начала кайнозоя, вызванного вымиранием энанциорнисовых («противоположных птиц») с низким кинетизмом черепа, которые не могли охотиться за мелкими насекомыми, и быстрой радиацией неогнат в низких широтах. В камбейском янтаре найден самый мелкий (2 мм) термит Nanotermes (древнейшая термитида). Сильная миниатюризация древнейших термитид могла быть причиной потери ими облигатного симбиоза с простейшими, населяющими кишечник низших термитов. Эти протисты оказались слишком крупны для узкого кишечника мелких рабочих древнейших термитид. Независимость от симбиоза с простейшими привела к потере термитидами большинства личиночных стадий и необратимому обособлению касты рабочих, которое обоусловило их экологическое доминирование в тропиках.

Как цитировать эту статью: Perkovsky E.E., Vasilenko D.V. 2020. Evolution of tropical termites in early Paleogene with description of a new species of Stylotermitidae (Isoptera) from Rovno amber (late Eocene of Ukraine) // Invert. Zool. Vol.17. No.3. P.231-246. doi: 10.15298/invertzool.17.3.03

КЛЮЧЕВЫЕ СЛОВА. Parastylotermes nathani sp.n., Nanotermes, Enantiornithes, миниатюризация, Termitidae, потеря облигатного симбиоза с кишечными простейшими, экологическое доминирование. 


\section{Introduction}

Until recently, only one termite species with trimerous tarsi, Baltic Parastylotermes robustus (Rosen, 1913) was known from amber, it was described in details by Emerson (1971). Wings of this species were reported by Emerson (1971) from Danish amber as well. Finding the second Priabonian species of the genus is especially interesting, because the recently resurrected family of Stylotermitidae (Engel, 2009) now contains three genera with trimerous tarsi - Ypresian Prostylotermes Engel et Grimaldi, 2011, Miocene-Ypresian Parastylotermes Snyder et Emerson, 1949 (both with tibial spur formula 22-2) and extant Stylotermes Holmgren et Holmgren, 1917 (Oriental, reaching the southern borders of Palearctic, tibial spur formula 32-2). Trimerous tarsi, wing venation, forewing scale setation and tibial spur formula 2-2-2 (Fig. $2 \mathrm{C}$ ) attribute the new species to the genus Parastylotermes.

The fauna of Priabonian amber forests is a mix of the temperate and tropical elements, while the temperate elements strongly prevail (Archibald, Farrell, 2003; Perkovsky, 2013, 2016, 2017; Ivanov et al., 2016). In Rovno amber forest, the tropical elements are represented better (Perkovsky, 2018; Lyubarsky, Perkovsky, 2019; Perkovsky et al., 2020 and references therein) than in Baltic amber forest. The temperate elements in Priabonian amber fauna of termites are represented by rhinotermitid Reticulitermes Holmgren, 1913 (Emerson, 1971) and Archotermopsidae. The tropical elements are represented by Mastotermitidae, Heterotermes Froggatt, 1897 (Emerson, 1971; Engel, 2008), Proelectrotermes Rosen, 1913 that is most diverse in Burmese amber (Engel et al., 2007a) and Electrotermes Rosen, 1913 (known from Oise amber; closely related extant Postelectrotermes Krishna, 1961 is known outside of tropics only from Baluchistan and Madeira); the distribution of extinct and extant stylotermitids in Old World allows adding them to this group.

Holotype of the new species was collected in Rovno region. Paratype K-8878 was mined in
Pugach quarry (Klesov) in 2009. Paratype L139 was collected near Voronki village (see Martynova et al., 2019), Vladimirets district of Rovno region, in the same piece with holotype of formicine ant Cataglyphoides dlusskyi Radchenko et Khomich, 2020 (Radchenko, Khomich, 2020). All studied material is deposited in the collection of the Schmalhausen Institute of Zoology (SIZK) in Kiev.

\section{Parastylotermes nathani Perkovsky sp.n.} Figs 1, 2.

Material. Holotype: SIZK UA-5704, Rovno amber, late Eocene; syninclusion: Hemiptera, Drepanosiphidae. Paratypes: SIZK K-8878, Klesov, Rovno amber, late Eocene, syninclusions: Hybotidae, Isoptera wing; SIZK L-139, Voronki, Vladimirets district, Rovno amber, late Eocene (syninclusions listed in Radchenko, Khomich, 2020).

DIAGNOSIS: New species differs from the other representatives of the genus, except Cambay amber Parastylotermes krishnai Engel et Grimaldi, 2011, by the short (length of forewing of the other species - 9.4-10.7 mm) and narrow (Fig. 1A, B, F) wings (forewing of the other species 1.8-2.6 times as long as wide), from bigger Baltic Parastylotermes robustus also by 18 -segmented antennae of holotype and Klesov specimen ( $P$. robustus have 16-17-segmented antennae, in new species 16-segmented antennae known only for the small specimen from Voronki) and $\mathrm{CuA}$ with 11 primary branches reaching to posterior wing margin (P. robustus by Engel et al., 2011 have 7-8); P. krishnai differs from both new species and $P$. robustus by 14-segmented antennae and the apical branching of the medial vein in the forewing.

DESCRIPTION. Body brown. Head and pronotum with strong setae, with maximal setae length $0.19 \mathrm{~mm}$ (Figs 1C, 2A, E, G), more dark on the head and light brown on wing scales and abdomen.

Head dark brown. Postclypeus (Fig. 1C, D) convex, short, 4.3 times as wide as long, with shallow impression in middle (Fig. 2A). Anterior margin of postclypeus not emarginated. Fon- 

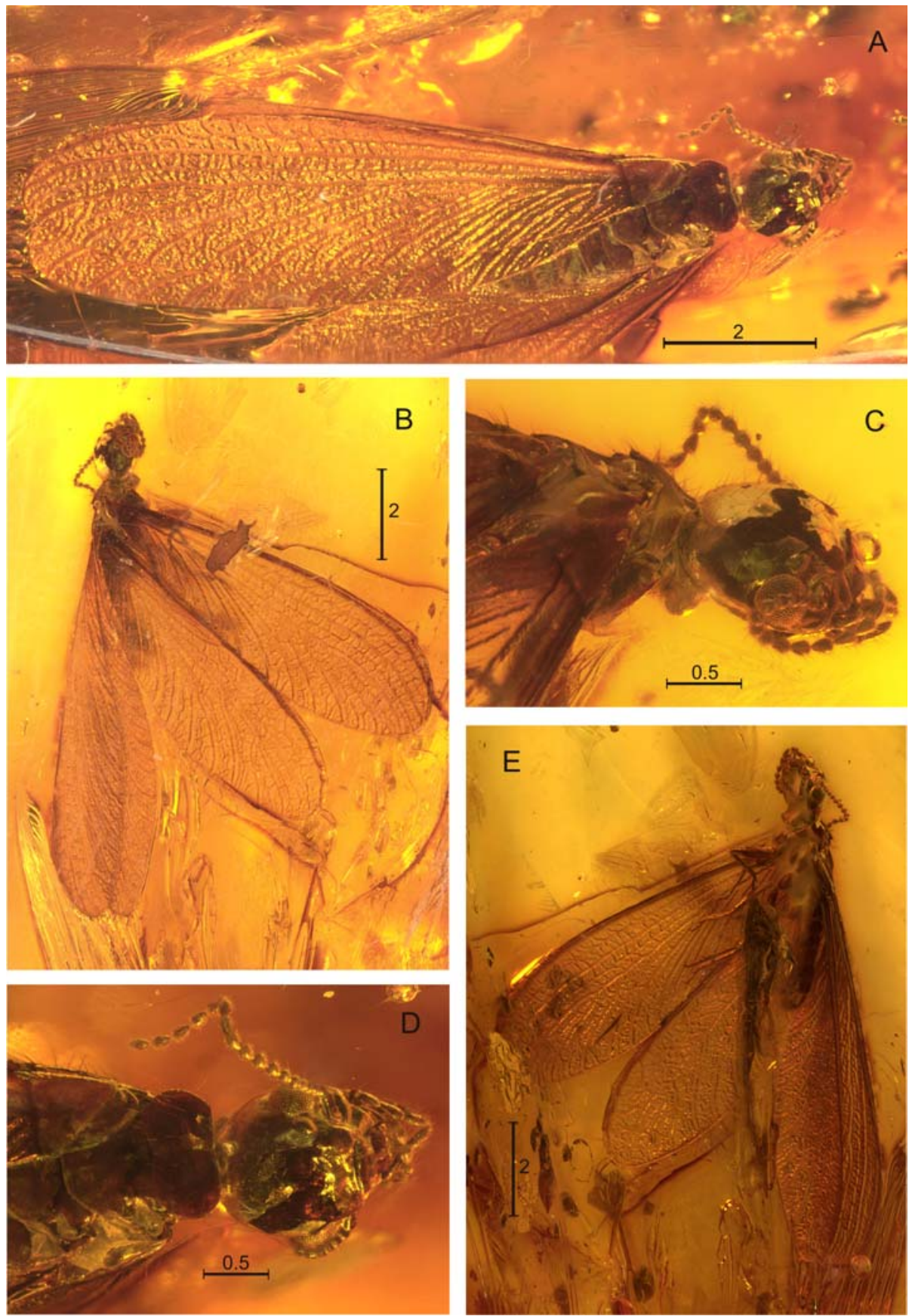

Fig. 1. General view and details of structures of Parastylotermes nathani sp.n., holotype A - left wings; B - general view, dorsal; C - head and antennae, dorsolateral; D - proximal part of body, dorsal; E general view, ventrolateral.

Рис. 1. Общий вид и детали строения голотипа Parastylotermes nathani sp.n. А - левые крылья; В общий вид, сверху; С — голова и антенны, в верхнебоковом положении; D — голова и проксимальная часть крыла, сверху; Е - общий вид, в нижнебоковом положении. 

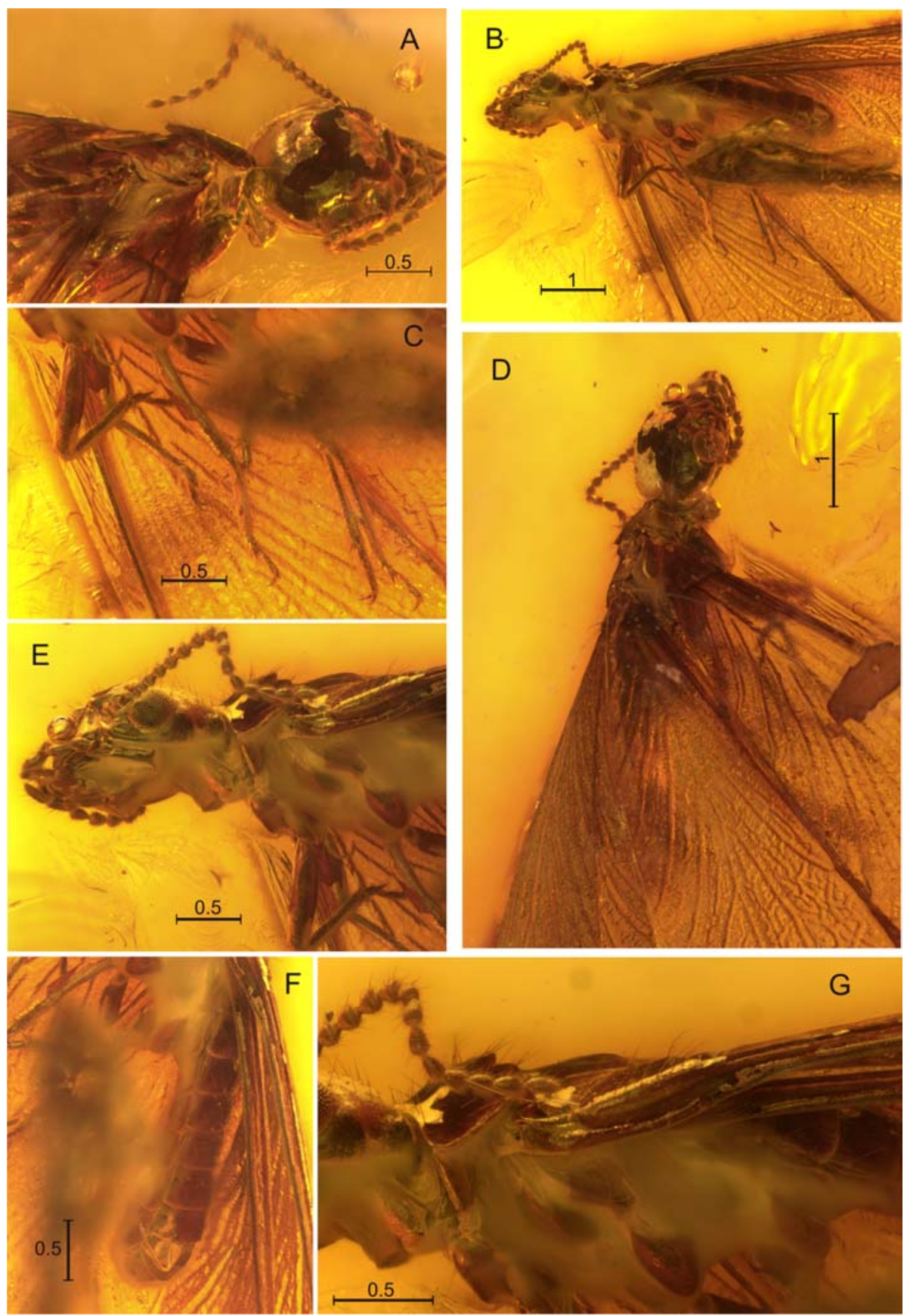

Fig. 2. Microphotographs of details of structures of Parastylotermes nathani sp.n, holotype. A - head, dorsolateral; B - body, lateral; C - legs, D - proximal parts of right wings; E - head and thorax, ventrolateral; F - abdomen; $\mathrm{G}$ - pronotum and left forewing scale, lateral

Рис. 2. Микрофотографии деталей строения голотипа Parastylotermes nathani sp.n. А - голова в верхнебоковом положении; В - тело, сбоку; С — ноги; D — проксимальная часть правых крыльев; $\mathrm{E}$ - голова и грудь, в нижнебоковом положении; F - брюшко; $\mathrm{G}$ - пронотум и левая переднекрыловая чешуйка, сбоку. 
tanelle small, its front margin situated on the level of hind margin of eyes (Fig. 1C); four maxillary palpomeres, three labial palpomeres. Antennae of holotype (Fig. 2E). and paratype K-8878 18-segmented, antennae of paratype L139 16-segmented.

Pronotum wide and flat, shallow longitudinal groove in middle (Fig. 1D); front margin with slight indentation in middle. Pronotum widest before middle. anterior and posterior angles widely rounded, hind margin distinctly emarginate with a shallow angle in middle.

Legs light brown; tibial spur formula 2-2-2, additional spines on tibiae absent. Tarsi trimerous, apical tarsomere longer than combined lengths of basitarsus and second tarsomere (Fig. $2 \mathrm{C}$ ), second tarsomere projecting apically beneath base of apical tarsomere (Fig. 2C, E); pretarsal claws simple, arolium absent.

Forewing scale large, overlapping the two thirds of hind wing scale, humeral margin slightly convex, apical margin straight. CuP (claval fissure) strongly curved in the lower fifth of its length, scale with numerous long, erect setae, particularly along humeral margin, without short setae (Figs 1C, 2G). C and R more darkly pigmented than remaining veins; $\mathrm{M}$ in middle of wing more close to $\mathrm{CuA}$ than to $\mathrm{R}, \mathrm{CuA}$ with 11 primary branches reaching posterior wing margin. Forewing 3-3.2 times as long as wide. Hind wing scale with straight apical margin (suture). Abdomen brown (Fig. 2F), tergites and sternites with long setae.

Measurements (in $\mathrm{mm}$ ). Total length with wings $8.6-11$, total length without wings $4.3-$ 5.5 , length of head to hind margin of postclypeus 1 , length of head to front margin of clypeus 1.2 ; width of head with eyes $1.15-1.3$ (holotype 1.3), length of postclypeus 0.07 , width of postclypeus 0.3 , maximum diameter of eye $0.38-0.4$ (holotype 0.4 ), eye height 0.35 , length of ocellus 0.18 , width of ocellus 0.09 , ocellus from eye 0.04 , distance between eye and lower head margin $0.05-0.1$ (holotype 0.05 ), length of pronotum 0.5 , width of pronotum $0.82-1.05$, length of hind tibia 1.2, length of forewing from costal suture 6.3-7.8; forewing width 1.95-2.6; distance between $\mathrm{C}$ and $\mathrm{R}$ on forewing 0.2 , distance between $\mathrm{R}$ and $\mathrm{M}$ in the middle of forewing 0.5 , distance between $\mathrm{M}$ and $\mathrm{Cu}$ in the middle of forewing 0.4 ; length of forewing scale $0.9-1$; length of hind wing 6.2 ; width of hind wing $1.8-2.5$; length of hind wing scale $0.6-0.69$.

ETYMOLOGY. The new species is named for Nathan E. Perkovsky (1988-2020).

\section{Discussion}

Stylotermitidae is the sister group of all remaining Neoisoptera (Krishna et al., 2013; Wu et al., 2018). Stylotermitid colonies are small, without discrete nests, found in living and partially dead trees (Krishna et al., 2013; Liang et al., 2017). The species described is the second Priabonian termite with trimerous tarsi, and thus $15 \%$ of Priabonian amber termite species have trimerous tarsi (Engel et al., 2007b; Engel, 2008; this paper). In Ypresian resins, termites with trimerous tarsi compose half of all species, and they compose $75 \%$ in Cambay amber ( $\mathrm{Nel}$, Bourguet, 2006; Engel et al., 2011); half of the Cambay species are stylotermitids. The statistic on the proportion of trimerous vs. tetramerous and pentamerous termites in Ypresian resins are based on too few specimens to be absolutely accurate, but we can indicate that $42 \%$ of Cambay specimens $(26 \%$ of all known Ypresian specimens) belong to genera with trimerous tarsi. Trimerous tarsi are uncommon among the extant termites, as shown by the global fauna, in which only $2.3 \%$ have trimerous tarsi: Of 2937 extant species, only 45 Stylotermes Holmgren et Holmgren, 1917 (Stylotermitidae), 12 Speculitermes Wasmann, 1902 (Termitidae) species and 10 Indotermes Roonwal et Sen-Sarma, 1958 (Termitidae) species (Krishna et al., 2013) have trimerous tarsi. All these three extant genera are distributed in the Oriental Realm. Even on the Indian subcontinent and Burma where species with trimerous tarsi are relatively common and diverse, they compose just 6\% of termite species (Roonwal, Chhotani, 1989; Chhottani, 1997).

In addition to their abundance (see below), Cambay termites are also very small (Table 1). Ypresian stylotermitids are much smaller (imagoes are $4.0 \mathrm{~mm}$ long [Parastylotermes krish- 
Table 1. Body length of Burmese and Cambay amber termites. Таблица 1. Длина тела термитов из бирманского и камбейского янтаря.

\begin{tabular}{|c|c|c|c|c|}
\hline No & Species & $\begin{array}{l}\text { Body length of } \\
\text { alate without } \\
\text { wings }(\mathrm{mm})\end{array}$ & Deposit and age & Reference \\
\hline 1 & $\begin{array}{l}\text { Mylacrotermes } \\
\text { cordatus }\end{array}$ & 5.95 & $\begin{array}{l}\text { Burmese amber, } \\
\text { Cenomanian }\end{array}$ & $\begin{array}{l}\text { Engel et al., } \\
\text { 2007a, Fig. } 6\end{array}$ \\
\hline 2 & $\begin{array}{l}\text { Dharmatermes } \\
\text { avernalis }\end{array}$ & 5.3 & $\begin{array}{l}\text { Burmese amber, } \\
\text { Cenomanian }\end{array}$ & $\begin{array}{l}\text { Engel et al., } \\
\text { 2007a, Fig. } 7\end{array}$ \\
\hline 3 & Tanytermes anawrahtai & 5.3 & $\begin{array}{l}\text { Burmese amber, } \\
\text { Cenomanian }\end{array}$ & $\begin{array}{l}\text { Engel et al., } \\
2007 \mathrm{a}\end{array}$ \\
\hline 4 & Kachinitermes tristis & 3.95 & $\begin{array}{l}\text { Burmese amber, } \\
\text { Cenomanian }\end{array}$ & Emerson, 1969 \\
\hline 5 & Ginormotermes rex & ca 24 & $\begin{array}{l}\text { Burmese amber, } \\
\text { Cenomanian }\end{array}$ & $\begin{array}{l}\text { Engel et al., } \\
2016\end{array}$ \\
\hline 6 & Krishnatermes yoddha & 10.04 & $\begin{array}{l}\text { Burmese amber, } \\
\text { Cenomanian }\end{array}$ & $\begin{array}{l}\text { Engel et al., } \\
2016\end{array}$ \\
\hline 7 & Anisotermes xiai & 12.6 & $\begin{array}{l}\text { Burmese amber, } \\
\text { Cenomanian }\end{array}$ & $\begin{array}{l}\text { Zhao et al., } \\
2019\end{array}$ \\
\hline 8 & $\begin{array}{l}\text { Kachinitermopsis } \\
\text { burmensis }\end{array}$ & 3.3 & $\begin{array}{l}\text { Burmese amber, } \\
\text { Cenomanian }\end{array}$ & Poinar, 2009 \\
\hline 9 & Cosmotermes opacus & 5.9 & $\begin{array}{l}\text { Burmese amber, } \\
\text { Cenomanian }\end{array}$ & $\begin{array}{l}\text { Zhao et al., } \\
2020\end{array}$ \\
\hline \multicolumn{2}{|c|}{$\begin{array}{l}\text { Average body length of } \\
\text { Burmese species* }\end{array}$} & \multicolumn{2}{|c|}{8.5} & Our data \\
\hline 10 & $\begin{array}{l}\text { Parastylotermes } \\
\text { krishnai }\end{array}$ & 4 & $\begin{array}{l}\text { Cambay amber, } \\
\text { Ypresian }\end{array}$ & $\begin{array}{l}\text { Engel et al., } \\
2011\end{array}$ \\
\hline 11 & $\begin{array}{l}\text { Prostylotermes } \\
\text { kamboja }\end{array}$ & 4.4 & $\begin{array}{l}\text { Cambay amber, } \\
\text { Ypresian }\end{array}$ & $\begin{array}{l}\text { Engel et al., } \\
2011\end{array}$ \\
\hline 12 & Zophotermes ashoki & 4.9 & $\begin{array}{l}\text { Cambay amber, } \\
\text { Ypresian }\end{array}$ & $\begin{array}{l}\text { Engel et al., } \\
2011\end{array}$ \\
\hline 13 & Nanotermes isaacae & ca 2 & $\begin{array}{l}\text { Cambay amber, } \\
\text { Ypresian }\end{array}$ & $\begin{array}{l}\text { Engel et al., } \\
2011\end{array}$ \\
\hline \multicolumn{2}{|c|}{$\begin{array}{l}\text { Average body length of } \\
\text { Cambay species }\end{array}$} & \multicolumn{2}{|c|}{3.7} & Our data \\
\hline
\end{tabular}

*Only one representative of genus is counted.

nai Engel et Grimaldi, 2011] and 3.8 or $5.0 \mathrm{~mm}$ [male, female Prostylotermes kamboja Engel et Grimaldi, 2011]) than extant Indian Stylotermes (medium body length $7.6 \mathrm{~mm}$ ) (Roonwal, Chhotani, 1989). Cambay isopterans (Table 1) are 2.3 times smaller than the 'mid'-Cretaceous Burmese amber isopterans; termites from Albian Spanish amber are even larger than termites from Burmite: Ithytermes montoyai SánchezGarcía, Peñalver, Delclòs et Engel, 2020 is 9.6 mm (Sánchez-García et al., 2020), and the head and pronotum of Morazatermes krishnai Engel et Delclòs, 2010 is $6 \mathrm{~mm}$ long (Engel, Delclòs, 2010). Aptian Crato species are mostly largebodied (Grimaldi et al., 2008), 2.6 times larger than Cambay species, with the length of the Aptian Siberian Baissatermes lapideus Engel, Grimaldi et Krishna, 2007 ca. $10 \mathrm{~mm}$ (Engel et al., 2007a, fig. 1), near the medium length of Crato species $(9.5 \mathrm{~mm})$. Finally, Cambay ter- 
mites are two times smaller than Ypresian Oise isopterans (see details below).

All Cambay amber termites belong to Neoisoptera. All known Ypresian and the single Cretaceous Neoisoptera Archeorhinotermes rossi Krishna et Grimaldi, 2003 are small; it reflects unidirectional decrease in size as general pattern of termite evolution (Nalepa, 2011). Amitermes parvus (Hill, 1922), the smallest from 120 termites, used in work of Nalepa (2011), have median adult head width of 0.67 $\mathrm{mm}$ and was indicated as undoubtedly miniaturized species. Head width of Archeorhinotermes rossi is $0.69 \mathrm{~mm}$ (Krishna, Grimaldi, 2003), so it is not less miniaturized. With the development of the fontanelle (possession of fontanelle defines Neoisoptera), termites evolved a highly effective new defense mechanism — the frontal weapon. Ants are undoubtedly the most important termite invertebrate predators (Deligne et al., 1981) now-a-day, and probably also in the Cenozoic. The frontal weapon appears particularly useful to protect against numerous ant species in the tropics, such as individually foraging small-colony ponerines, including the arboreal Platythyrea Roger, 1863, known from the Early Eocene of Europe. Neoisopterans are not recorded in Oise amber and middle Eocene Eckfeld, and rare in the latest Eocene Bembridge Marls. In succinites (Priabonian ambers), more 'basal' termite groups are very strongly represented, whereas only a third of Baltic amber species belong to Neoisoptera (Engel et al., 2007b; Engel, 2008). In the late Oligocene lacustrine outcrops of Aix-enProvence and Camoins-les-Bains (France), Neoisoptera are also quite rare (only two alate specimens) while the Mastotermitidae are frequent (ca. 20 alates) (Nel, pers. com). In the diverse Miocene termite fauna of New Zealand (six genera), neoisopterans are completely absent (Engel, Kaulfuss, 2017). The absolute dominance of Neoisoptera at the species level has been documented from the large samples found only in Miocene tropical ambers (Krishna et al., 2013), and even in Dominican amber, the number of kalotermid and mastotermitid specimens among the named species is comparable to the number of neoisopterans. The reasons for the absence of 'lower' termites in Cambay amber may be because of diverse and relatively numerous ants ( $6 \%$ of all inclusions: Parker, Grimaldi, 2014), but the tropical ant fauna of this amber (Rust et al., 2010) remains undescribed. In coeval Oise amber, ants represent $2.5 \%$ of all insects (Parker, Grimaldi, 2014), and neoisopterans are absent. Krishna \& Grimaldi (2009: 4344) noted that "kalotermitids feed and nest in sound wood, and so would be expected to have been living in close proximity to copious resin... the scarcity of kalotermitids in Dominican amber may reflect a genuine absence of these termites in the amber forest, and not just an absence of data". In our opinion, this statement is also true for the absence of kalotermitids in Cambay amber.

Roisin (2000) indicated that a correlation can be drawn between the "one-piece" life type termites (OPT), that is, living within a piece of wood serving simultaneously as a nest and as a food source, and a Kalotermes Hagen, 1853 like caste pattern, characterized by the presence of pseudergates (pseudoworkers) and the absence of workers. The only Ypresian termite that is larger than the Priabonian congeners and Cretaceous representatives of a closely related genus, and indeed the largest of all Ypresian termites, is the kalotermitid Electotermes flecki Nel et Bourguet, 2006 from Oise amber, an OPT species. Paradoxically, it is even larger than Mastotermes minutus Nel et Bourguet, 2006 from Oise amber, while in all other faunas where kalotermitids and Mastotermitidae Froggatt, 1897 occur together (from the earliest Cenomanian till the present), mastotermitids are 2-2.5 times larger than kalotermitids.

Separate life-type species (ST), sensu Korb \& Thorne (Korb, Thorne, 2017), have a nest that is separate from their multiple food sites. All known Neoisoptera are ST type species. ST here comprises "intermediate-type" termites nesting in and feeding on wood but able to expand their colonies by exploiting several pieces of wood through subterranean tunnels (Roi$\sin , 2000)$ as well as the true "separate life" nesting termites where colonies are found in the 
soil. Of the "intermediate-type" Ypresian amber termites, we can include Mastotermes, who by this time had real workers, and Zophotermes Engel, 2011, with their supposed Prorhinotermes-like pseudergates. "Intermediate-type" species also include Reticulitermes, a typical example, as well as some Termitidae, such as Microcerotermes parvus (Haviland, 1898) (Roisin, 2000), and others. Cambay amber termites, e.g. small stylotermitids and very small termitids, were probably all ST species ("intermediatetype" or true "separate-life"). The stylotermitid caste system remains unknown (Wu et al., 2018); however, soldiers are known, and the worker caste is always mentioned and deserves additional investigation (Liang et al., 2017). Miniaturization was accompanied by a decrease in the number of tarsomeres (to 3) and antennomeres (to 12 in Nanotermes Engel et Grimaldi, 2011) and a loss of a third foretibial spur in all Cambay termites.

Termites in Cambay amber compose $1.7 \%$ all insect inclusions. Their colonies were small in size (the size of foragers is discussed in detail below), and therefore would not have attracted the attention of specialized predators; e.g. extant stylotermitids (see above) is the most cryptic Taiwan isopterans (Liang et al., 2017). Zophotermes belongs to Prorhinotermitinae (Krishna et al., 2013), which differ from most neoisopterans by having pseudergate workers. Pseudergate workers are favored when termites live in small, short-lived, unstable societies under highly uncertain environmental conditions (Thompson et al., 2000).

Compared to social Hymenoptera, termites appear to be very vulnerable insects; there is strong pressure favoring adaptations that minimize their predation (Noirot, 1985). Miniaturization of Cambay termites could be associated with changes in predation pressure from generalists in the Paleocene tropics, resulting in a decrease in size of tropical termites by the early Eocene.

Pressure from a generalist predator would be especially important because the existence of specialized termite predators in the Cambay amber forest is highly doubtful. After reapprais- ing the Sakhalinian amber age (Baranov et al., 2015; Radchenko, Perkovsky, 2016), only 'basal' aneuretine ants from Paskapoo (LaPolla, Barden, 2018), and, possibly, ant from Menat, described as a member of the Eumenidae (Archibald et al., 2018 and references therein) of the Paleocene are known. The PaleoceneEocene was the most important time in the diversification of ants (LaPolla et al., 2013), but it is believed that the widespread distribution of ants with large colonies which would be able to launch raids on termites occurred much later than the beginning of the Eocene (Perkovsky, Wegierek, 2018 and references therein). Famous fossil pangolins, such as Eurotamandua Storch, 1981, Eomanis Storch, 1978 and Euromanis Storch et Martin, 1994 from Messel (Germany), are much younger than the age of Cambay amber (Lenz et al., 2015). We do not agree with Bourguignon et al. (2017) that ant and termite specialists began by preying on termites, adding ants to their diet later, because the arrival of termites predates mammalian myrmecophagy. Most myrmecophages eat both termites and ants, and in all Paleogene faunas, ants were much more numerous and diverse than termites. Mammals that specialize on termites do not appear until the Miocene, when termitids were very common. In the rich vertebrate fauna of the Tadkeshwar lignite mine, where all Cambay termites have been mined, even Insectivora are absent (Smith et al., 2016), and the primitive primates present were definitely not entomophagous (Bajpai et al., 2008).

The most important termite predators among lizards are the Scincidae (Deligne et al., 1981; Feylininae (ex. Feylinidae) now included in Scincidae), but all named Cretaceous scincids are described from the Santonian-Campanian of Alberta; Canadian amber yields only a single unnamed termite. Fauna of Canadian amber belong not to Isoptera realm, but to Baeomorpha realm, where termites are very uncommon (Gumovsky et al., 2018). After this time and until the Priabonian, a single named scincid is known from the late Paleocene of France, and its specialization on termites is highly unlikely. Other more common and important termite pred- 
ators among lizards, listed by Deligne et al. (1981), are Pygopodidae and Dibamidae, that have not been found as fossils until Oligocene (Dibamidae) or Miocene (Pygopodidae) (Hutchinson, 1997; Čerňanský, 2019). Snakes that regularly predate termites (Typhlopidae and Colubridae: Calamarinae) are unknown as fossils or absent until the late Oligocene.

One of the End Cretaceous extinctions could have been especially important for increasing selection pressure on the earliest Paleogene Indian termites, i.e. the extinction of opposite birds (Enantiornithes) that dominated the low latitudes during the Cretaceous (Mayr, 2017; Perkovsky et al., 2018 and references therein) and supposed explosive radiation of crown birds (Neornithes; Field et al., 2020b). Fossils of Cretaceous arboreal crown birds are unknown. Thus far, only Maastrichtian diving and littoral crown birds have been described (Mayr et al., 2018; Field et al., 2020a). Birds are important, well-known termite predators, but opposite birds with limited cranial kinesis could not catch small insects (ca $10 \mathrm{~mm}$ and less) (Perkovsky et $a l ., 2019,2020$ and references therein). Therefore, workers and soldiers of most Kachin amber termites were probably free from avian pressure, as were the workers and soldiers (ca 5-6 mm) of the most common Crato termite, Meiatermes araripena Krishna, 1990 (more than $70 \%$ of all Crato termites, Grimaldi et al., 2008), and the single Barremian Spanish Meiatermes worker which is slightly bigger $(7.2 \mathrm{~mm}$ : Martínez-Delclòs, Martinell, 1995). Most crown birds belong to Neognathae, with advanced cranial kinesis permitting the swallowing of insects do not need to toss them in the air as opposite birds, and therefore they were able to easily feed on insects less than $1 \mathrm{~cm}$ in length (Perkovsky et al., 2020). However, it seems that most of the regular avian predators of wingless termites were absent in the Ypresian tropics, at least in the Cambay amber forest. The most important extant arboreal avian predators of wingless termites are woodpeckers (Vasconcelos et al., 2015), but advanced Eucavitaves were not present in the Ypresian, although there were arboreal birds that could hunt for small insects, such as the small, thin-beaked Upupiformes (Zelenkov, pers. comm.). Now common termite predators include Phasianidae, Numididae, Otididae, Motacillidae and certain small Ploceidae (Deligne et al., 1981), none of which were present in the Ypresian.

The avian material from the Vastan lignite mine (one of the Cambay amber mining locations) is dominated by Vastanavis-like coracoids, of which 25 were found (Mayr et al., 2010,2013). No other type of coracoid is known from the locality (Mayr et al., 2010). Vastanavis Mayr et al., 2007 have also been reported from the Tadkeshwar lignite mine (Smith et al., 2016). Vastanavis is assigned to Vastanavidae (Psittaciformes). They are not small and are unlikely to have had a small, thin bill. Most primitive termites had small colonies, and small size of alates could limits at least the number of firstbrood eggs. The apparent absence of specialized avian ant and termite predators suggests that a decrease in the size of workers and soldiers reduced the attractiveness of termites as prey for generalist birds. Stylotermitid workers were 2.3-4 mm long (Engel et al., 2016, Table S3), and Zophotermes pseudergates were 2-4 $\mathrm{mm}$ long. Nanotermes workers should be less than $1.5 \mathrm{~mm}$ (possibly much less: in the smallest known extant Termitinae from India and Sri Lanka [e.g. Pericapritermes ceylonicus (Holmgren, 1911) and Krishnacapritermes maitii Chhotani, 1997), workers are only 0.6-0.7 mm length of alates]. We do not know the size of Nanotermes colonies, but the size of its sterile castes would be too small for generalist avian predators. A decrease of termite size in Cambay amber could be one of the reasons that they reached their maximum relative abundance in the Paleogene, $1.7 \%$ of all Cambay insects. For comparison, termite inclusions from the nearly contemporary Oise amber (neoisopterans absent) make up less than $0.05 \%$. Miniaturization may also explain the eponymous small size of imagines of Mastotermes minutus from Oise amber ( $7 \mathrm{~mm}, \mathrm{Nel}$, pers. comm.). The species is two times smaller than Miocene $M$. electrodominicus Krishna et Grimaldi, 1991, who was the smallest mastotermitid till the description of 
M. minutus. Other species of the genus are up to three times larger than M. minutus. Large protist symbionts (up to $0.55 \mathrm{~mm}$ in extant Mastotermes) are damaged and digested in a small termite's gut, so for Mastotermes, the possibility of size reduction is even more limited than in other lower termites (see below). M. minutus head width is $1.9 \mathrm{~mm}$, it is not far from head width of third instar of subsocial cockroach Cryptocercus punctulatus Scudder, 1862 averages $1.28 \mathrm{~mm}$ (by Nalepa, 2011); it narrows the gap between Mastotemitidae and all other termite families (by Nalepa, 2011 at least some termite species from these families may be described as miniaturized). Smaller foragers (4$5.7 \mathrm{~mm}$; 0.6-0.8 length of alates, see Engel et al., 2016, Table S3) would attract less attention from generalist predators, but their symbiosis with protists would be not very effective. Cohabitation of Mastotermes of minutus size with any ST type termite (including neoisopterans) is unknown. With the appearance of specialized ant and termite predators among mammals, as well as ants with large colonies attacking termites in the late Early Eocene (LaPolla et al., 2013; Perkovsky, Wegierek, 2018), the predators became less selective, and the adaptive reasons of termite miniaturization drastically decreased.

The smallest and most interesting Cambay termite is the most ancient termitid, Nanotermes. It is the world's smallest termite, with the body length of alates at $2 \mathrm{~mm}$, and also has trimerous tarsi. Termitidae is the isopteran family that ecologically dominates extant tropical forests. Almost certainly, "the origin and early diversification of the Termitidae was within sub-Saharan Africa" (Krischna et al., 2013: 168). They were already present in the early Ypresian in insular India, and the estimation of their divergence from rhinotermitids (Bucek et al., 2019) in the earliest Paleocene is reasonable. Miniaturization of termitids appears to be a pre-adaptation that seems important for their future diversification. The size of termitid colonies can reach millions of individuals, although some 'primitive' soil feeders retain relatively smaller colonies (Krishna et al., 2013). Termiti- dae have a worker caste that is strictly sterile. They constitute the vast majority of extant termite species $(80 \%)$ and are the ecologically dominant taxa in tropics (Bourguignon et al., 2017). Moving forward in time, the next undoubtable termitid from the terminal Oligocene of France is not large (body length of alate is 5 $\mathrm{mm} ; \mathrm{Nel}, 1984)$. Only in Dominican amber do some amber termitids reach $8 \mathrm{~mm}$.

Very small termites (such as Nanotermes, workers of Ypresian stylotermitids and small pseudergates of Zophotermes) would not attract significant attention from birds. Modern smallsized insectivorous birds try to catch a larger prey and do not forage on small creatures (Zelenkov, pers. comm.) according to observations. Cambay amber flea beetles appear very small compared to extant tropical Alticini (Nadein, Perkovsky, 2019), probably for the same reason. Miniaturization experienced by ancient termitids influenced the simplification of their venation as well.

Thus, the dominance of small termites with trimerous tarsi in Cambay amber is likely related to changes in the nature of predatory pressure in the tropics of the earliest Cenozoic caused by the extinction of opposite birds and rapid radiation of crown birds at low latitudes. In turn, the small sizes of early Neoisoptera facilitated the appearance of a sterile worker caste. The developmental pathway of all Termitidae bifurcates at the first molt after the first externally undifferentiated larval instar (Noirot, 1969). The irreversible separation of neuter and sexual lines in higher termites, apparent after the first molt, is not surprising given that in the course of their evolution, termitids achieved a degree of miniaturization observed in Nanotermes. In $1.5 \mathrm{~mm}$ long Nanotermes workers, or $2.4 \mathrm{~mm}$ extant Indian workers, the presence of more than two larval instars and one worker instar is unnecessary, since molting requires energy, and the workers of oldest termitids would be small. In more 'basal' (and larger) lower termites, there are three larval instars and up to eight worker instars (Roisin, 2000), partly influenced by their symbiosis with protists (see below). Small workers are known among extant termitids from 
different subfamilies; thus, on the Indian subcontinent, only workers of 2.4-3.5 mm are known for 28 species ( $15 \%$ of all Indian termitids for which the length of workers is known), among which there are even two species with dimorphic workers. For another 79 species (43\%), at least some of the workers are smaller than $4 \mathrm{~mm}$ (Roonwal, Chhotani, 1989; Chhottani, 1997). For lower termites, workers of 2.74-3.5 mm are known in only three species (two of these are insular or known only from the type locality), which comprises $4 \%$ of the total Indian subcontinent lower termites for which the lengths of workers or pseudergates are known. For another 18 species ( $23 \%$ of lower termites), at least some workers are smaller than $4 \mathrm{~mm}$, and all except two of them belong to Neoisoptera (Roonwal, Chhotani, 1989). The small size of Paleogene termitids may be especially important because many termitids forage in the open (Engel et al., 2009), making them more conspicuous to predators. Interestingly, the mentioned single named Oligocene Termitidae (from Southern France; Nel, 1984) is also miniaturized. The length of its body without wings is $5 \mathrm{~mm}$. Eightyseven percent of extant Indian termitid species for which the body lengths without wings are reported are larger, while all Indian workers (with one exclusion) from species with imaginal body lengths shorter than $5 \mathrm{~mm}$ have body lengths between 2.7-4.6 mm (Roonwal, Chhotani, 1989; Chhottani, 1997).

An orphan group of Stylotermes halumicus Liang et al., 2017 with fewer than 50 workers and soldiers that was kept in the laboratory started producing replacement reproductives within 6 months (Wu et al., 2018). These data suggest that Stylotermes has a linear developmental pathway similar to that of the Prorhinotermes Silvestri, 1909 (Wu et al., 2018), Psammotermes Desneux, 1902 and Termitogeton Desneux, 1904. The mesonotum and metanotum of Stylotermes workers, in contrast to those of termitids, can bear long pleural processes (Roonwal, Chhotani, 1989). Colonies of Stylotermes are likely composed of no more than a few hundred individuals (Wu et al., 2018: small to medium nests in the referenced Tsai et al.,
1978). Symbiotic protists in lower termites can be transmitted only by anal trophallaxis, and it strongly influences its caste system. Reasons for the extinction of most stylotermitids are discussed below.

A feature of social evolution in the most basal termites is that the resources of the colony are inherited by neotenics (secondary reproductives with juvenile morphological characters). In the most 'basal' families (Mastotermitidae, Archotermopsidae, Stolotermitidae), all genera produce neotenics, while the percentage of termitid genera producing neotenics does not exceed 16\% (Higashi et al., 2000). This is a strong argument for retaining the flexibility of developmental pathways in lower termites that tend not to nest in ephemeral dead branches of living trees (Higashi et al., 2000). An indicator of eusociality is reproductive skew, defined as the probability that workers and soldiers forego direct reproduction $(0$, all colony members reproduce; 1 , all colony members except a single colony breeder forego direct reproduction) (Higashi et al., 2000). Reproductive skew equals $0-0.25$ in Architermopsidae and Stolotermitidae and close to 1 in most Termitidae (Higashi et al., 2000).

Contrary to Engel et al. (2009), we cannot judge whether Termitidae were abundant during the Eocene in Africa or even other tropical regions based on their absence in Baltic amber because the Baltic amber forest climate was equable (Nadein et al., 2016 and references therein). Extant lower termites with protist symbionts are much better adapted to life outside of the tropics than higher termites (termitids) that originated in the African tropics with their complex of bacterial symbionts. Termite species richness drops very rapidly from roughly $10^{\circ}$ north and south of the equator. Species richness at $48^{\circ} \mathrm{N}$ and $\mathrm{S}$ is only $1-4 \%$ of the richness at the Equator (Eggleton, 2000). Because the age of succinites is Priabonian (Perkovsky et al., 2007) (contra Engel et al., 2009), termite abundance in ambers was $0.2-0.3 \%$ at $48^{\circ} \mathrm{N}$ in the Priabonian but already nearly $2 \%$ in the tropics in the Ypresian. Regarding that the first spike in abundance is due not only to the diversification of the Termitidae (Engel et al., 2009) and Rhinoter- 
mitidae but also to the diversification of Stylotermitidae, it is evident that at least in the early Paleogene of tropical Asia, the role of Stylotermitidae was much more significant than in the extant fauna. Three species have been named from the Miocene of California and Washington as well (Krishna et al., 2013). The inability to compete with termitids resulted in stylotermitids becoming a relict group.

Future studies of termite-symbiont coevolution can profoundly change our understanding of their geographical distribution (cf. Perkovsky, Wegierek, 2018). The single successful temperate rhinotermid genus Reticulitermes has protist symbionts in common with East Asian archotermopsids, absent in all other rhinotermitids (Gile et al., 2018 and references therein). The absence of neoisopterans from the Miocene of New Zealand is meaningful as well.

Engel et al. (2009) suggested that social evolution is like any other highly adaptive feature, such as the evolution of flight in dinosaurs, and thus may take tens of millions of years to refine. It appears it took much longer for termites to reach ecological dominance compared to ants (Engel et al., 2009). The reasons why lower termites that appear in the geological record of the earliest Cretaceous (Vršanský, Aristov, 2014) are nowhere near reaching ecological dominance are understandable now: there are limitations imposed by protist symbionts, requiring more time for the evolution of ecological dominance.

As indicated by Engel et al. (2009: 13), "eusociality per se does not result in ecological success, but living in very large colonies with extreme division of labor does". Gut prokaryotes replaced gut protozoa as the key digestive symbionts in the still mostly wood-eating most recent common ancestor of Termitidae (Bucek et al., 2019). For higher termites, the loss of the obligate symbiosis with intestinal Protozoa is of the same importance as ants having a close symbiosis with hemipterans. Honeydew gathering dolichoderines and formicines developed a characteristic proventriculus that allows the crop to carry large amounts of liquid (Perkovsky, Wegierek, 2018 and references therein). The association of lower termites with protists pre- vented their ecological dominance, and to reach it, termites required much more time.

Termites have their own cellulases, but the loss of key digestive symbionts would be induced by the very strong selective pressure for miniaturization. The extreme miniaturization of the termitid ancestor (the average head width of Nanotermes equals $6 \%$ of that of Cryptocercus punctulatus) was influenced by the rapid diversification of crown birds and their expansion in the low latitudes following the extinction of opposite birds, and this very well corresponds to the estimated age of divergence between Termitidae and their sister clade at 64.9 Ma (Bucek et al., 2019). The hindgut symbionts of lower termites are not fully established until the third or fourth instar (Nalepa, 2011 and references therein). The third instar of the oldest termitids was too small to allow the establishment of hindgut symbionts. Later, the third instar was lost. It leads to the irreversible separation of neuter and sexual lines. Obtaining new gut biota and switching to soil feeding or acquiring external symbionts by the many termitid lineages (Bucek et al., 2019) were just consequences of extreme miniaturization of their common ancestors.

\section{Compliance with ethical standards}

CONFLICT OF INTEREST: The authors declare that they have no conflict of interest.

\section{Acknowledgements}

We are grateful to Nikolay R. Khomich (Rovno) for help with acquiring the paratype, Anatoly P. Vlaskin (SIZK) for cutting and primary polishing of the samples, Sergej A. Simutnik (SIZK) for photos, Alexandr P. Rasnitsyn (Paleontological Institute, Moscow) for fruitful discussion and help with details of venation, André Nel (Muséum national d'Histoire naturelle, Paris) for useful discussion and permission to use his unpublished data on French material.

\section{References}

Archibald B., Farrell B.D. 2003. Wheeler's dilemma // Acta Zoologica Cracoviensia. Vol.46 (Supplement Fossil Insects). P.17-23. 
Archibald S.B., Rasnitsyn A.P., Brothers D.J., Mathewes R.W. 2018. Modernisation of the Hymenoptera: ants, bees, wasps, and sawflies of the early Eocene Okanagan Highlands of western North America // Canadian Entomologist. Vol.150. P.205-257.

Bajpai S., Kay R.F., Williams B.A., Das D.P., Kapur V.V., Tiwari B.N. 2008. The oldest Asian record of Anthropoidea // Proceedings of the National Academy of Sciences of the United States of America. Vol.105. No.32. P.11093-11098. https://doi.org/10.1073/ pnas.0804159105

Baranov V., Andersen T., Perkovsky E.E. 2015. Orthoclads from Eocene Amber from Sakhalin (Diptera: Chironomidae, Orthocladiinae) // Insect Systematics \& Evolution. Vol.46. P.359-378. https://doi.org/10.1163/ $1876312 \mathrm{X}-45032122$

Bouju V., Perrichot V. 2020. A review of amber and copal occurrences in Africa and their paleontological significance // BSGF - Earth Sciences Bulletin. Vol.191. $17 \mathrm{p}$.

Bourguignon T., Lo N., Šobotník J., Ho S.Y.W., Iqbal N., Coissac E., Lee M., Jendryka M.M., Sillam-Dussè D., Kř́̌žkova B., Roisin Y., Evans T.A. 2017. Mitochondrial phylogenomics resolves the global spread of higher termites, ecosystem engineers of the tropics // Molecular Biology and Evolution. Vol.34. P.589-597.

Bucek A., Šobotník J., He S., Shi M., McMahon D.P., Holmes E.C., Roisin Y., Lo N., Bourguignon T. 2019. Evolution of termite symbiosis informed by transcriptome-based phylogenies // Current Biology. Vol.29. Is.21. P.3728-3734.e4. https://doi.org/10.1016/j.cub. 2019.08.076

Čerňanský A. 2019. The first potential fossil record of a dibamid reptile (Squamata: Dibamidae): a new taxon from the early Oligocene of Central Mongolia // Zoological Journal of the Linnean Society. Vol.187. Is.3. P.782-799.

Chhotani O.B. 1997. The fauna of India and the adjacent countries. Isoptera(Termites): (family Termitidae). Vol.2. Calcutta: Zoological Survey of India, $x x+800$ pp.

Deligne J., Quennedey A., Blum M.S. 1981. The enemies and defense mechanisms of termites // H.R. Hermann (ed.). Social Insects, Vol. II. New York: Academic Press. P.1-76.

Eggleton P. 2000. Global patterns of termite diversity // T. Abe, D.E. Bignell, M. Higashi (eds.). Termites: evolution, sociality, symbioses, ecology. Dordrecht: Kluwer Academic Publishers. P.25-51.

Emerson A.E. 1969. A revision of the Tertiary fossil species of the Kalotermitidae (Isoptera) // American Museum Novitates. No.2359. P.1-57.

Emerson A.E. 1971. Tertiary fossil species of the Rhinotermitidae (Isoptera), phylogeny of genera, and reciprocal phylogeny of associated Flagellata (Protozoa) and the Staphylinidae (Coleoptera) // Bulletin of the American Museum of Natural History. Vol.146. No.3. P.243-303.

Engel M.S. 2008. Two new termites in Baltic amber (Isoptera) // Journal of the Kansas Entomological Society. Vol.81. No.3. P.194-203.
Engel M.S. 2019. Termite evolution: A primal knock on wood or a hearty mouthful of dirt // Current Biology. Vol.29. Is.21. P.R1126-R1129. https://doi.org/10. 1016/j.cub.2019.09.016

Engel M.S., Barden P., Riccio M.L., Grimaldi D.A. 2016. Morphologically specialized termite castes and advanced sociality in the Early Cretaceous // Current Biology. Vol.22. Is.4. P.522-530.

Engel M.S., Delclòs X. 2010. Primitive termites in Cretaceous amber from Spain and Canada (Isoptera) // Journal of the Kansas Entomological Society. Vol.83. No.2. P.111-128.

Engel M.S., Grimaldi D.A., Krishna K. 2007a. Primitive termites from the Early Cretaceous of Asia (Isoptera) // Stuttgarter Beiträge zur Naturkunde. Serie B, Geologie und Paläontologie. Vol.371. P.1-32.

Engel M.S., Grimaldi D.A., Krishna K. 2007b. A synopsis of Baltic amber termites (Isoptera) // Stuttgarter Beiträge zur Naturkunde. Serie B, Geologie und Paläontologie. Vol.372. P.1-20.

Engel M.S., Grimaldi D.A., Krishna K. 2009. Termites (Isoptera): their phylogeny, classification, and rise to ecological dominance // American Museum Novitates. No.3650. P.1-27.

Engel M.S., Grimaldi D.A., Nascimbene P.C., Singh H. 2011. The termites of Early Eocene Cambay amber, with the earliest record of the Termitidae (Isoptera) // ZooKeys. Vol.148. P.105-123.

Engel M.S., Kaulfuss U. 2017. Diverse, primitive termites (Isoptera: Kalotermitidae, incertae sedis) from the early Miocene of New Zealand // Austral Entomology. Vol.56. P.94-103.

Field D.J., Benito J., Chen A., Jagt J.W.M., Ksepka D.T. 2020a. Late Cretaceous neornithine from Europe illuminates the origins of crown birds // Nature. Vol.579. P.397-401.

Field D.J., Berv J.S., Hsiang A.Y., Lanfear R., Landis M.J., Dornburg A. 2020b. Chapter 5 Timing the extant avian radiation: The rise of modern birds, and the importance of modeling molecular rate variation // M. Pittman, X. Xu (eds.). Pennaraptoran theropod dinosaurs: past progress and new frontiers. Bulletin of the American Museum of Natural History. Vol.440. No.1. P.159-181.

Gile G.H., James E.R., Taic V., Harperd J.T., Merrella T.J., Boscaro V., Husník F., Scheffrahn R.H., Keeling P.J. 2018. New species of Spirotrichonympha from Reticulitermes and the relationships among genera in Spirotrichonymphea (Parabasalia) // Journal of Eukaryotic Microbiology. Vol.65. No.2. P.159-169.

Grimaldi D.A., Engel M.S., Krishna K. 2008. The species of Isoptera (Insecta) from the Early Cretaceous Crato formation: a revision // American Museum Novitates. No.3626. P.1-30.

Gumovsky A., Perkovsky E., Rasnitsyn A. 2018. Laurasian ancestors and "Gondwanan" descendants of Rotoitidae (Hymenoptera: Chalcidoidea): What a review of Late Cretaceous Baeomorpha revealed // Cretaceous Research. Vol.84. P.286-322. https://doi. org/10.1016/j.cretres.2017.10.027 
Higashi M., Yamamura N., Abe T. 2000. Theories on the sociality of termites // T. Abe, D.E. Bignell, M. Higashi (eds.). Termites: evolution, sociality, symbioses, ecology. Dordrecht: Kluwer Academic Publishers. P.169-187.

Hutchinson M.N. 1997. The first fossil pygopod (Squamata, Gekkota), and a review of mandibular variation in living species // Memoirs of the Queensland Museum. Vol.41. Is.2. P.355-366.p

Ivanov V.D., Melnitsky S.I., Perkovsky E.E. 2016. [Caddisflies from Cenozoic resins of Europe] // Paleontologicheskii Zhurnal. No.5. P.53-61 [in Russian; English translation: Paleontological Journal. Vol.50. No.5. P.485-493].

Korb J., Thorne B. 2017. Sociality in termites // D. Rubenstein, P. Abbot (eds.). Comparative social evolution. Cambridge: Cambridge University Press. P.124-153.

Krishna K., Grimaldi D.A. 2003. The first Cretaceous Rhinotermitidae (Isoptera): a new species, genus, and subfamily in Burmese amber // American Museum Novitates. No.3390. P.1-10.

Krishna K., Grimaldi D.A. 2009. Diverse Rhinotermitidae and Termitidae (Isoptera) in Dominican Amber // American Museum Novitates. No.3640. P.1-48.

Krishna K., Grimaldi D.A., Krishna V., Engel M.S. 2013. Treatise on the Isoptera of the world // Bulletin of the American Museum of Natural History. Vol.377. P.12704.

LaPolla J.S, Dlussky G.M., Perrichot V. 2013. Ants and the Fossil Record // Annual Review of Entomology. Vol.58. P.609-630.

Lenz O.K., Wilde V., Mertz D.F., Riegel W. 2015. New palynology-based astronomical and revised ${ }^{40} \mathrm{Ar} /{ }^{39} \mathrm{Ar}$ ages for the Eocene maar lake of Messel (Germany) // International Journal of Earth Sciences. Vol.104. P.873-889.

Liang W.-R., Wu C.-C., Li H.-F. 2017. Discovery of a cryptic termite genus, Stylotermes (Isoptera: Stylotermitidae), in Taiwan, with the description of a new species // Annual Review of Entomology. Vol.110. P.360-373. https://doi.org/10.1093/aesa/sax034

Lyubarsky G.Yu., Perkovsky E.E. 2019. First species of Ephistemus (Coleoptera:Clavicornia: Cryptophagidae) from Baltic amber // Russian Entomological Journal. Vol.28. No.1. P.54-57. https://doi.org/10.15298/ rusentj.28.1.07

Martínez-Delclòs X., Martinell J. 1995. The oldest known record of social insects // Journal of Paleontology. Vol.69. No.3. P.594-599.

Martynova K.V., Perkovsky E.E., Olmi M., Vasilenko D.V. 2019. New records of Upper Eocene chrysidoid wasps (Hymenoptera: Chrysidoidea) from basins of Styr and Stokhod rivers (Rovno amber) // Paleontological Journal. Vol.53. No.10. P.998-1023.

Mayr G. 2017. Avian evolution. The fossil record of birds and its paleobiological significance. Chichester: J. Wiley \& Sons. 293 p.

Mayr G., De Pietri V.L., Scofield R.P., Worthy T.H. 2018. On the taxonomic composition and phylogenetic affinities of the recently proposed clade Vegaviidae
Agnolín et al., 2017-neornithine birds from the Upper Cretaceous of the Southern Hemisphere // Cretaceous Research. Vol.86. P.178-185.

Mayr G., Rana R.S., Rose K., Sahni A., Kumar K., Singh L., Smith Th. 2010. Quercypsitta-like birds from the Early Eocene of India (Aves, ?Psittaciformes) // Journal of Vertebrate Paleontology. Vol.30. No.2. P. 467478. https://doi.org/10.1080/02724631003617357.

Mayr G., Rana R.S., Rose K.D., Sahni A., Kumar K., Smith Th. 2013. New specimens of the early Eocene bird Vastanavis and the interrelationships of stem group Psittaciformes // Paleontological Journal. Vol.47. No.11. P.1308-1314. https://doi.org/10.1134/ S0031030113110105

Nadein K.S., Perkovsky E.E. 2019. Small and common: the oldest tropical Chrysomelidae (Insecta: Coleoptera) from the lower Eocene Cambay amber of India // Alcheringa: An Australasian Journal of Palaeontology. Vol.43. No.4. P.597-611.

Nadein K.S., Perkovsky E.E., Moseyko A.G. 2016. New Late Eocene Chrysomelidae (Insecta: Coleoptera) from Baltic, Rovno and Danish ambers // Papers in Palaeontology. Vol.2. No.1. P.117-137.

Nalepa C.A. 2011. Body size and termite evolution // Evolutionary Biology. Vol.38. P.243-257.

Nel A. 1984. Description d'une nouvelle espèce de termite fossile du stampien d'Aix-en-Provence (Dictyoptera, Termitidae, Termitinae) // Entomologica Gallica. Vol.1. No.3. P.159-160.

Nel A., Bourguet E. 2006. Termite[s] of the early Eocene amber of France (Isoptera: Mastotermitidae, Kalotermitidae) // Neues Jahrbuch für Geologie und Paläontologie Monatschefte. No.2. P.101-115.

Noirot C. 1969. Formation of castes in the higher termites // K. Krishna, F.M. Weesner (eds.). Biology of termites. Vol.1. New York: Academic Press. P.311-350.

Noirot C. 1985. The caste system in higher termites // J.A.L. Watson, B.M. Okot-Kotber, C. Noirot (eds.). Current themes in tropical science. Vol.3. Caste differentiation in social insects. Oxford: Pegamon Press. P.75-86.

Parker J., Grimaldi D.A. 2014. Specialized myrmecophily at the ecological dawn of modern ants // Current Biology. Vol.24. P.2428-2434. http://dx.doi.org/ 10.1016/j.cub.2014.08.068

Perkovsky E.E. 2013. [Eohelea sinuosa (Meunier, 1904) (Diptera, Ceratopogonidae) in Late Eocene ambers of Europe] // Paleontologicheskii Zhurnal. 2013. No.5. P.44-52 [in Russian; English translation: Paleontological Journal. Vol.47. No.5. P.503-512] https:// doi.org/10.7868/S0031031X1304017X

Perkovsky E.E. 2016. Tropical and Holarctic ants in Late Eocene ambers // Vestnik zoologii. Vol.50. No.2. P.111-122.

Perkovsky E.E. 2017. Comparison of biting midges of the Early Eocene Cambay amber (India) and Late Eocene European ambers supports the independent origin of European ambers // Vestnik zoologii. Vol.51. No.4. P.275-284.

Perkovsky E.E. 2018. Only a half of species of Hymenoptera in Rovno amber is common with Baltic 
amber // Vestnik zoologii. Vol.52. No.5. P.353-360. Perkovsky E.E., Martynova E.V., Mita T., Olmi M.., Zheng Y., Zhang Q., Gantier F., Perrichot V. 2020. A golden age for ectoparasitoids of Embiodea: Cretaceous Sclerogibbidae (Hymenoptera, Chrysidoidea) from Kachin (Myanmar), Charentes (France) and Choshi (Japan) ambers // Gondwana Research. Vol.87. P.1-22.

Perkovsky E.E., Olmi M., Müller P., Martynova K.V. 2019. A review of the genus Hybristodryinus Engel, 2005 (Hymenoptera, Dryinidae) from mid-Cretaceous Burmese amber, with a discussion on its phylogenetic significance // Cretaceous Research. Vol.99. P.169189.

Perkovsky E.E., Olmi M., Vasilenko D.V., Capradossi L., Guglielmino A. 2020. First Bocchus Ashmead (Hymenoptera: Dryinidae) from Upper Eocene Rovno amber: B. schmalhauseni sp. nov.//Zootaxa. Vol.4819. No.3. P.544-556. https://doi.org/10.11646/zootaxa.4819.3.6

Perkovsky E.E., Rasnitsyn A.P., Vlaskin A.P., Taraschuk M.V. 2007. A comparative analysis of the Baltic and Rovno amber arthropod faunas: representative samples // African Invertebrates. Vol.48. No.1. P.229245.

Perkovsky E.E., Sukhomlin E.B., Zelenkov N.V. 2018. An unexpectedly abundant new genus of black flies (Diptera, Simuliidae) from Upper Cretaceous Taimyr amber of Ugolyak, with discussion of the early evolution of birds at high latitudes // Cretaceous Research. Vol.90. P.80-89.

Perkovsky E., Wegierek P. 2018. Aphid-Buchnera-Ant symbiosis; or why are aphids rare in the tropics and very rare further south? // Earth and Environmental Science. Transactions of the Royal Society of Edinburgh. Vol.107. P.297-310.

Poinar G.O. 2009. Description of an early Cretaceous termite (Isoptera: Kalotermitidae) and its associated intestinal protozoa, with comments on their co-evolution // Parasites Vectors. Vol.2: 12. http://www. parasitesandvectors.com/content/2/1/12

Radchenko A.G., Khomych M.R. 2020. Ants of the extinct genus Cataglyphoides Dlussky, 2008 (Hymenoptera: Formicidae: Formicinae) from the late Eocene European ambers // Invertebrate Zoology. Vol.17. No.2. P.154-161. https://doi.org/10.15298/invertzool. 17.2.05

Radchenko A.G., Perkovsky E.E. 2016. The ant Aphaenogaster dlusskyana sp. nov. (Hymenoptera, Formicidae) from the Sakhalin amber — the earliest described species of an extant genus of Myrmicinae // Paleontological Journal. Vol.50. No.9. P.936-946.

Roisin Y. 2000. Diversity and evolution of caste patterns // T. Abe, D.E. Bignell, M. Higashi (eds.). Termites: evolution, sociality, symbioses, ecology. Dordrecht: Kluwer Academic Publishers. P.95-119.
Roonwal M.L., Chhotani O.B. 1989. The fauna of India and adjacent countries. Isoptera (termites). (Introduction and families Termopsidae, Hodotermitidae, Kalotermitidae, Rhinotermitidae, Stylotermitidae and Indotermitidae). Vol.1. Calcutta: Zoological Survey of India. viii $+672 \mathrm{pp}$.

Rust J., Singh H., Rana R.S., McCann T., Singh L., Anderson K., Sarkar N., Nascimbene P.C., Stebner F. et al. 2010. Biogeographic and evolutionary implications of a diverse paleobiota in amber from the early Eocene of India // Proceedings of the National Academy of Sciences of the United States of America. Vol.107. No.43. P.18360-18365.

Sánchez-García A., Peñalver E., Delclòs X., Engel M.S. 2020. Early Cretaceous termites in amber from northern Spain (Isoptera) // Cretaceous Research. Vol.110. 104385.

Smith T., Kumar K., Rana R.S., Folie A., Sole F., Noiret C., Steeman T., Sahni A., Rose K. 2016. New early Eocene vertebrate assemblage from western India reveals a mixed fauna of European and Gondwana affinities // Geoscience Frontiers. Vol.7. P.969-1001.

Thompson G.J., Kitade O., Lo N., Crozier R.H. 2000. Phylogenetic evidence for a single, ancestral origin of a 'true'worker caste in termites // Journal of Evolutionary Biology. Vol.13. P.869-881.

Tsai P.-H., Ping C.-K., Li G.-X. 1978. [Four new species of the genus Stylotermes Holmgren, K. et N. (Isoptera: Rhinotermitidae, Stylotermitinae) from Kwangsi] // Acta Entomologica Sinica. Vol.21. No.4. P.429-436 [in Chinese, with English summary]

Vasconcelos M.F., Hoffmann D., Araújo M.C., Vasconcelos P.N. 2015. Bird-termite interactions in Brazil: A review with perspectives for future studies // Biota Neotropica. Vol.15. No.1: e20140035 http://dx.doi. org/10.1590/1676-06032014003514

Vršanský P., Aristov D. 2014. Termites (Isoptera) from the Jurassic/ Cretaceous boundary: Evidence for the longevity of their earliest genera // European Journal of Entomology. Vol.111. No.1. P.137-141. https://doi. org/10.14411/eje.2014.014

Wu L.-W., Bourguignon T., Šobotník J., Wen P., Liang W.-R., Li H.-F. 2018. Phylogenetic position of the enigmatic termite family Stylotermitidae (Insecta: Blattodea) // Invertebrate Systematics. Vol.32. No.5. P.1111-1117. https://doi.org/10.1071/IS17093

Zhao Z., Eggleton P., Yin X., Gao T., Shih C., Ren D. 2019. The oldest known mastotermitids (Blattodea: Termitoidae) and phylogeny of basal termites // Systematic Entomology. Vol.44. P.612-623. https://doi. org/10.1111/syen.12344

Zhao Z., Yin X., Shih C.K., Gao T., Ren D. 2020. Termite colonies from mid-Cretaceous Myanmar demonstrate their early eusocial lifestyle in damp wood // National Science Review. Vol.7. P.381-390.

Responsible editor K.G. Mikhailov 